\title{
ANTAGONIZM I MOŻLIWOŚĆ DIALOGU W EUROPEJSKIM SPORZE O PŁEĆ
}

\section{WSTĘP}

Artykuł dotyczy aktualnie toczącego się sporu o rolę ludzkiej płci w życiu społecznym, o jej wartość oraz możliwość dialogu. W sporze udział biorą z jednej strony ruchy lewicowe, mające różne rodowody filozoficzno-ideologiczne, a z drugiej strony przedstawiciele prawicowi, stojący na gruncie wartości tradycyjnych, najczęściej związani z europejskim chrześcijaństwem. Obecnie spór ten ma bardzo ostry, wręcz konfrontacyjny wyraz zarówno w licznych publikacjach na temat roli płci, jak i w mas smediach, a także przebiega przez podziały polityczne. Spór antagonizuje życie społeczne, lecz należy mimo wszystko szukać możliwości kulturowej debaty, czyli form jakiegoś dialogu w imię wspólnego dobra. Czyżby strony sporu nie miały nic, co mogłoby być pouczające dla strony przeciwnej? W artykule najpierw porusza się zagadnienie źródeł, następnie - na ile ten postulat choćby tylko próby poznania racji drugiej strony jest możliwy oraz jakie należy uwzględnić wstępne warunki.

* Ks. dr Stefan Ewertowski - adiunkt w Zakładzie Filozofii i Kultury Chrześcijańskiej na Wydziale Teologii UWM w Olsztynie; redaktor naczelny "Studiów Elbląskich”. 


\section{KULTUROWE ŹRÓDłA}

Humanista stara się poznać przyczyny oraz źródła społecznych zjawisk. Europa przeszła długą drogę, by dopiero po wielu, nawet tragicznych doświadczeniach XX wieku dojść do "nowej ideologii seksualnej oraz rozumienia znaczenia płci”. W tropieniu źródeł idei nie trzeba cofać się do początków cywilizacji europejskiej. Chrześcijańska kultura najpierw doznała ideowego pęknięcia w czasach reformacji, gdy w imię wolności nurty protestanckie postanowiły uwolnić się spod autorytetu Kościoła. Niewątpliwie poszerzył się zakres myślenia indywidualnego i autonomicznego. Człowiek sam stawał się miarą rzeczy, miarą słuszności oraz wyrocznią dobra i zła. O odrzuceniu dekalogu jako moralnego fundamentu Europy na początku czasów nowożytnych jednak jeszcze nie myślano.

Europejskie oświecenie stanowiło kolejną próbę emancypacji spod wpływu myślenia metafizycznego, który mimo wszystko podlegał chrześcijańskiej inspiracji. W uzasadnianiu czynu pojawił się jednak naturalizm etyczny. Jest to postawa filozoficzna, która nie dostrzega związku pomiędzy faktami a powinnością. D. Hume negował właśnie ten związek - ,jest” i „powinieneś”. W XX wieku do tego stanowiska nawiązał G. E. Moore, który twierdził, że dobra nie da się zdefiniować. Jest to odejście od myślenia substancjalnego na rzecz myślenia o znakach myśli. W poznaniu substancjalnym - essencjalnym - można poznać „dyspozycje i potencjalności”, a przez to poznać powinności. Tak uzasadniano odczytanie istnienia prawa naturalnego ,jako międzyosobowej relacji nacechowanej powinnością działania lub zaprzestanie działania ze względu na dobro osoby"1. Czyżby rzeczywiście fakt spotkania drugiego człowieka nie stwarzał relacji powinności? Takie relacje obojętności mogłyby realizować jedynie cyborgi. Jednak mimo wszystko w kulturze europejskiej zakwestionowano istnienie prawa naturalnego na rzecz promowania prawa pozytywnego, którego jedynym i ostatecznym źródłem jest człowiek i jego wola. Natura ludzka w znaczeniu klasycznej filozofii, w całym jej integralnym bycie, przestała być kryterium postępowania. Zakwestionowana została możliwość prawa naturalnego, ponieważ w myśl nowożytnych założeń z opisu funkcjonowania określonych prawidłowości biologicznych związanych z naturalnymi inklinacjami człowieka nie wynikają wnioski normatywne. Co w zamian?

Odchodząc od chrześcijańskiej metafizyki, szukając legitymizacji prawa oraz norm moralnych zarówno H. Grotius, T. Hobbes, J. Locke, B. Spinoza, S. Puffendorf, W. Leibniz, Ch. Wolff, T. Christian, M. H. Monteskiusz oraz

${ }^{1}$ M. A. Krąiec, Naturalizm etyczny, w: Powszechna encyklopedia filozofii, Lublin 2006, t. 7 , s. 530-531. 
J. J. Rousseau odwoływali się do ludzkiej natury, ale rozumianej już w aspekcie społecznym bądź przyrodniczym. Proceduralne rozumienie prawa prowadziło do umowy społecznej, a psychologiczne osadzenie prawa w ludzkiej naturze uwzględniało instynkt samozachowawczy i egoizm, na który jedynym lekarstwem jest rezygnacja z uprawnień jednostkowych na podstawie wspólnej umowy, jako woli powszechnej². Dążenia wolitywne, cele pragmatyczne zwyciężyły nawet apodyktyczne kryteria poznawcze. W ten sposób otwarto drogę relatywizmu etycznego oraz prawnego.

W rozumieniu europejskich prądów liberalnych jak też pozytywizmu prawnego i nurtu egzystencjalizmu nie istnieje obiektywna antropologia. Poznanie człowieka polega na interpretacji bądź intuicji, której jednak w żaden sposób nie można obiektywnie uzasadnić. Tak rozeszła się dziedzina faktyczności z dziedziną moralności. Natomiast bliżej moralności znalazła się polityka, czego przykładem może być choćby unijna „Karta Praw Podstawowych [która] odzwierciedlając te wszystkie oświeceniowe wartości, do których należy dążyć wzbudziła w Polsce duże obawy. Ten, [jak to nazwał znany publicysta M. Rybiński] «mistycyzm konstytucyjny», stawia sobie za cel stworzenie nowego europejskiego ludu, gdyż ten istniejący się już nie sprawdza"3. Niestety, nawet prawa człowieka w dzisiejszym dyskursie kulturowo-politycznym nie zawsze mogą być językiem etycznego porozumienia. Powyższe idee będą nieustannie się pojawiać. W sytuacji, gdy próbuje się zrozumieć i opisać funkcjonowanie kulturowego układu społecznego, arbitralność wartości, idee liberalne, indywidualizm wysuwają się na plan pierwszy.

Dawny porządek społeczny był bardziej stabilny, gdy pod uwagę weźmie się sytuację ochrony prawnej rodziny. W układzie państwowym władza kontrolowała zachowania jednostki. Instrumentami były prawo, edukacja i religia. Jednak taki stan rzeczy, zwłaszcza w myśli krytycznej, oceniany był jako „kontrola społeczna” lub „hegemonia społeczna”, która kojarzyła się z aparatem przemocy i ograniczaniem wolności. Konflikt narastał i był postrzegany zwłaszcza w konfrontacji kontroli burżuazyjnej - rządzącej klasy nad szerokimi masami, którym odmawiano prawa tej wolności, jaką cieszyły się elity. Brzmi to marksistowsko, jednak pragnienie szerszej wolności $\mathrm{w}$ przestrzeni moralnej napotykało na społeczną perswazję, kulturową hegemonię. P. Bourdieu mówił o „przemocy symbolicznej", która narzucała normy kultury ${ }^{4}$. Skoro historia Europy może być postrzegana jako nieustanna walka o wolność, to należy wskazać, jak doszło do poszerzenia jej zakresu. Procesy te, bardzo dobrze zaznaczyły się w kulturze masowej XX wieku. Nie sposób dokładnie opisać przemian w kategoriach

${ }^{2}$ J. Stelmach, R. Sarkowicz, Filozofia prawa XIX i XX wieku, Kraków 1999, s. 12-16.

${ }^{3}$ M. Brachowicz, Dlaczego Karta Praw Podstawowych UE budzi sprzeciw, „Międzynarodowy Przegląd Polityczny" 2007, nr 3 (19), s. 29.

${ }^{4}$ P. Burke, Historia i teoria społeczna, Warszawa-Karków 2000, s. 108-110. 
ewolucji, jak czynił to E. Durkheim. Można wskazywać na pośrednie przyczyny w nowoczesnych formach masowej komunikacji. Przenikaniu idei sprzyja możliwość przemieszczania się, rola biurokracji, działania rynku, a nawet takiego zjawiska społecznego, jak „utożsamianie wszystkiego, co nie «nowe», ze złem, co w efekcie prowadziło do fascynacji wszystkim, co «nowe» ${ }^{5}$.

Przemiany, jakie się dokonały pośród XIX-wiecznej industrializacji oraz XX-wiecznych procesów informatyzacji, mają swoją własną linię ewolucyjną. Jednakże już w XX wieku nie są to procesy przemian, ale radykalne momenty zerwania. Doktrynalną podstawę, jako rewolucyjne zerwanie m.in. w dziedzinie seksualności i płciowości, dał również egzystencjalizm. Warto powołać się na sztandarową postać XX-wiecznego egzystencjalizmu w osobie Jeana Paula Sartre'a. Francuski filozof, idąc za wskazaniami Martina Heideggera, zrywa z europejską metafizyką bytu. Znamienne jest jego twierdzenie: „Egzystencja poprzedza esencję"6. Dlatego Sartre dodaje: „Człowiek jest przede wszystkim projektem przeżywanym subiektywnie, miast być pianą, pleśnią czy kalafiorem. Przed tym projektem nic nie istnieje uprzednio, nic nie istnieje innego w sferze poznawalności. Człowiek przede wszystkim będzie tym, co stanowi realizację jego woli"7. Dodajmy jeszcze dwie deklaracje Sartre’a: „Inaczej mówiąc nie istnieje determinizm, człowiek jest wolny, człowiek jest wolnością"8; oraz deklarację związaną z czynem: „człowiek angażuje się w swoje życie, sam określa swoją postać i poza tą postacią nie ma nic ${ }^{\prime \prime}$. Człowiek więc w akcie moralnym tworzy siebie. Wybór nie jest całkowicie dowolny, bo jednak wybiera się w jakiejś sytuacji, ale też, jak napisze Sartre: „Kiedy stwierdzam, że wolność w każdej konkretnej okoliczności może mieć tylko jeden cel: dopełnienie siebie samej, to wskazuję, że jeżeli człowiek raz pojął, iż to on sam stwarza wartości, może pragnąć tylko jednego: wolności jako podstawy wszelkich innych wartości"10. W klimacie tych poglądów Simone de Beauvoir, więcej niż przyjaciółka Sartre’a i inicjatorka feministycznego ruchu, pisała swoją Druga płeć (1949), z przekonaniem, że „Kobietą nie można się urodzić; kobietą trzeba zostać!”. Taka deklaracja jest możliwa, ponieważ egzystencja jest „pusta”, należy ją stworzyć, nadać jej treść, a ponieważ człowiek jest wolny, kreacja też może być właściwie dowolna. Płci człowieka nie wyznacza biologia, lecz świadomość, która jest emanatem stosunków społecznych. Według funkcjonalnej teorii oraz socjokulturowego paradygmatu, nikt nie rodzi się mężczyzną lub kobietą, wszystko zależy od

5 Tamże, s. 164-166.

${ }^{6}$ J. P. Sartre, Problem bytu i nicości. Egzystencjalizm jest humanizmem, przeł. M. Kowalska, J. Krajewski, Warszawa 2001, s. 129.

7 Tamże, s. 132.

8 Tamże, s. 139.

9 Tamże, s. 149.

10 Tamże, s. 161. 
wzorców wychowania. To kultura, społeczne wzorce seksualności stwarzają płeć człowieka, która jednak nie jest ani ostateczna, ani stała. Jest to tylko konsekwencja powyższego sposobu myślenia. Odtąd filozofia "stawania się" będzie nieustannie rozwijana i politycznie wykorzystywana.

Francuski egzystencjalizm, zresztą jak i rozwijany w innych krajach, poza Gabrielem Marcelem czy Karlem Jasperem, w wydaniu społecznym wiązał się z marksizmem. Przecież to nie przypadek, bowiem według Marksa nie chodzi o poznanie prawdy, która wyznaczałaby działanie, lecz „świat trzeba zmieniać". Prawda jest "czymś”, co się staje w toku życiowej praktyki zmagania z przeciwieństwami. „Lepszy” świat trzeba dopiero stworzyć, ale najpierw trzeba zniszczyć stare systemy, zwłaszcza etyczne. Drogą i metodą jest rewolucja moralna, ona pozwoli na rewolucję polityczną. Zarówno Europą w XX wieku, jak i całym „Zachodem wstrząsa wojna kulturowa"11. Zwłaszcza w Polsce problematyka wolnego wyboru płci, dalej stosunku do homoseksualizmu i procesu tworzenia kolejnych praw dla mniejszości seksualnych, przy braku pomysłu lewicy na rozwiązywanie problemów społecznych, stała się sposobem jej politycznego istnienia. Właśnie te nurty całą rzeczywistość kulturową traktują jako pole walki o wpływy. Mowa jest tu o lewicy kulturowej oraz o politycznym populizmie ${ }^{12}$. W grę wchodzą również praktyki komercyjne.

W przekonaniu wielu, również współczesnych, ideologów założenie, że byt kształtuje świadomość, zyskało prawie status naukowego prawa! Jednak $\mathrm{w}$ drodze do kulturowego ignorowania różnicy płci trzeba było podjąć odpowiednie działania. $\mathrm{W}$ tym kierunku zmierza również polityka Komisji Europejskiej ${ }^{13}$. Marksizm zawsze będzie bliski lewicowym ruchom liberalnym oraz liberalnej demokracji, pozostaje jednak niewygodne pytanie o granice rewolucji moralno-społecznej. W 1945 roku Sartre wraz z Maric Merleau-Pontym założył lewicowe pismo „Les Temps Modernes”. Ten nurt międzynarodówki, bliski komunizmowi w wersji realizowanej w ZSRR ${ }^{14}$, tworzył klimat lewicowości, buntu wobec mieszczaństwa, kontestacji tradycyjnej, czyli chrześcijańskiej moralności. Kwestionował model rodziny, rozumienie płciowości oraz seksu-

${ }^{11}$ "Czy zmieniły się prawa człowieka w przeciągu ostatnich pięćdziesięciu lat? Wydaje się, że według autorów konstytucji, a zwłaszcza Karty Praw - tak. Prawa człowieka zastepuje droga do bezprawia - «prawa», których celem jest podważać i atakować tradycyjne instytucje naszej chrześcijańskiej cywilizacji, od prawa dożycia, poprzez definicję małżeństwa aż po ochronę starszych i chorych" - J. Daniska, Dlaczego chrześcijanie powinni odrzucić konstytucje europejska, "Międzynarodowy Przegląd Polityczny” 2005, nr 11, s. 33.

${ }^{12}$ K. Tomasik, Lewica dla gejów i lesbijek!, „Krytyka Polityczna” 2007, nr 11/12, s. $243-253$.

${ }^{13}$ Dobrobyt, solidarność $i$ bezpieczeństwo. Komisja Wspólnot Europejskich, Strategiczne cele na lata 2005-2009; Europa 2010: Partnerstwo dla odnowy europejskiej, „Międzynarodowy Przegląd Polityczny" 2005, nr 11, s. 157

${ }^{14}$ R. Scruton, Intelektualiści nowej lewicy, przeł. T. Pisarek, Poznań 1999, s. 260. 
alności. Znamienne jest wyznanie Doris Lessing, której przypisywano postawę feministyczną: „Nie znoszę Sartre’a i Beauvoir. To była para popisujących się komediantów. Życie, które niby prowadzili, to była jedna wielka bzdura. Przeczytałam wszystko, co napisali, i nigdy mnie to nie przekonało. Miałam wrażenie, że każdy może wypisywać takie rzeczy"15. Niestety, nie wszyscy intelektualiści byli tak krytyczni oraz zdystansowani do ideologicznych oraz filozoficznych poglądów socjalistycznych egzystencjalistów. W istocie te ideologie były jak iskra kulturowej rewolucji w Europie i na świecie, która właściwie zaczęła się i wybuchła w 1968 roku, lecz trwa nadal.

Swoistą teorię seksualności nurt rewolucyjny znalazł w koncepcji nie nowej, lecz bardzo wpływowej. Była to metoda psychoanalizy Zygmunta Freuda. Wiedeński neurolog i psychiatra proponował świadome uwolnienie „wypartego w podświadomość seksualnego życia człowieka”. „Świadomość stanowi jedynie zewnętrzną stronę ludzkiej psychiki, podczas gdy nieświadomość stanowi jej właściwe podłoże i istotę"16.

W powyższej koncepcji moralnego relatywizmu wszelkiego rodzaju narzucone ograniczenia i restrykcje w postaci kategoryzacji oraz norm kulturowych, również poprzez wychowanie i tradycję, uważa się za szkodzące człowiekowi. Powodują powstawanie nerwic i patologii. Co więcej, według tego nurtu interpretacji popędy seksualne stanowią klucz do zrozumienia człowieka, bowiem wszelkiego rodzaju nakazy, normy obyczajowe skierowane są na kształtowanie kultury ${ }^{17}$. Celem ataku lewicowych polityków był również system oświaty, gdzie wprowadzano liberalne metody wychowania i edukacji. Idee wyrosłe też z nihilizmu egzystencjalnego, takie jak rozumienie wolności jako amoralizmu, czego przykładem była zgoda na rynkową pornografię lub walka o legalną aborcję, przeniknęły do mass mediów. Opanowały twórców sztuki masowej, przygotowując w Europie przestrzeń genderowej rewolucji. Oczywiście nie sposób bardziej szczegółowo opisać w tym miejscu całego klimatu nakładających się na siebie nurtów i wydarzeń, które w istocie wyznaczają hierarchię wartości tworzoną we współczesnej kulturze. Chodziło tu o wskazanie tylko pewnych, najważniejszych źródeł, które mogą posłużyć zrozumieniu współczesnej polityki genderowej, zawartej również w KPP, a także w działaniach Komisji Europejskiej lub w postanowieniach Parlamentu Europejskiego. Polityka genderowa możliwa stała się przy założeniu, że najpierw odrzuca się „historyczne, filozoficzne i teologiczne źródła cywilizacji, ale i również to

${ }^{15}$ D. Lessing, Nie interesuja mnie żadne ideologie w rozmowie z M. Miecznika, „Dziennik” z 1-2 marca 2008, s. 18-19.

${ }^{16}$ P. Dybel, Vorlesungen zur Einführung In die Psychoanalise, w: Przewodnik po literaturze filozoficznej XX wieku, B. Skarga (red.), t. 1, Warszawa 1994, s. 83-84.

${ }^{17}$ Tamże, s. 83-94. 
wszystko, co może stanowić fundament pełnej solidarności międzyludzkiej"18. W przypadku KPP bezwarunkowo akcentuje prawa jednostki.

Europa w XX wieku przeszła przez różne wydarzenia medialne i przeobrażenia społeczne. Kobieta, ale i rodzina, wychowanie dzieci, płeć stały się źródłem ideologicznego sporu. Przytaczając przeróżne realne dramaty kobiet gwałconych, wykorzystywanych, samotnych, wielodzietnych, mordowanych podczas nielegalnych zabiegów aborcji, domagano się przede wszystkim wyzwolenia kobiety. Tworzono polityczne programy promocji oraz domagano się większego udziału kobiet w życiu publicznym, co pozostało aktualne do dziś.

Zawsze brakowało w kulturze integralnego spojrzenia na udział kobiety, ale i mężczyzny w akcie prokreacji. Mężczyzna, ewentualnie na wniosek kobiety, pociągany był do świadczeń alimentacyjnych. Te prawdziwe, lecz także emocjonalne nawiązania do losu samotnych kobiet, przypadków piętnowania osób homoseksualnych, molestowanych dzieci, aborcji itp. stanowią punkt odniesienia dla lewicy w jej programie wobec zagadnień płci.

Prawicowe ruchy również wskazują na konieczność obrony godności kobiety, na kształtowanie odpowiedzialności za akty seksualne, ale i tak były i są oskarżane o bezduszność. W praktyce medialnej, oświatowej ten kulturowy spór prawicowi przedstawiciele nieustannie przegrywali w sensie propagandowym. Dla lewicowej opcji najłatwiejsza okazała się droga w rozpowszechnianiu środków antykoncepcyjnych. W procesie tym pomagały często tylko rzekome osiągnięcia medycznych badań ludzkiej płodności i farmacja, która dostarczyła antynatalistycznego środka w postaci pigułki.

Jednak źródeł postmodernistycznego podejścia do kwestii wolności w ogóle, rozumienia kim jest człowiek w jego płciowości oraz nurtów genderowych przeobrażeń należy szukać przede wszystkim w europejskiej filozofii XX wieku. Inaczej niemożliwa byłaby liberalna moralność i niemożliwe byłyby poglądy o konieczności zapanowania nad płodnością, która przeszkadza w realizacji seksualnej swobody. Polskie ruchy lewicowe pod patronatem Federacji na Rzecz Kobiet i Planowania Rodziny szukały wsparcia w europejskich strukturach politycznych. Temu celowi służyć miała inicjatywa Listu Stu Kobiet, który skierowany był do Parlamentu Europejskiego. Działaczki zwracały uwagę na „fatalne położenie Polek oraz całkowite zideologizowanie kwestii ich praw reprodukcyjnych przez stronę kościelno-prawicową"19. W sporze - czy nawet otwartym konflikcie - strony przemawiają językiem z innych światów. Pamiętać należy, że lewica przemawia różnymi głosami, od anarchistów, poprzez intelektualistów tolerancji, po dogmatyków marksizmu. Obecnie m.in. poprzez eurożargon, język urzędników, język branżowych specjalistów, przez dyktat

\footnotetext{
${ }^{18}$ T. P. Terlikowski, Bogactwo wiary, "Nowe Państwo” 2008, nr 1, s. 16.

${ }^{19}$ K. Szczuka, Milczenie owieczek, „Krytyka Polityczna” 2002, nr 2, s. 265.
} 
wąskiej grupy urzędniczej narzuca się Europejczykom określony system wartości ${ }^{20}$. Język ten nie służy komunikacji, bowiem w zasadzie nie ma opisywać rzeczywistości, lecz ją kreować. Mówiąc nawet o prawach człowieka w KPP, język ten nie jest pozbawiony „ideologicznej neutralności”. Wszystko, co lewicowe, jest dobre, to, co prawicowe i konserwatywne, jest zawsze złe. W tym sposobie perswazji przejawia się swoista nowomowa, która oceniana jest albo z pozycji eurosceptyków, albo euroentuzjastów ${ }^{21}$. Sytuacja ta ukazuje, że spór o postrzeganie i praktyki w dziedzinie płci nie jest wolny od ideologicznego kontekstu.

Przedstawiciele genderowej rewolucji ani nie rozumieją, ani chyba nie chcą zrozumieć ludzi, którzy myślą według moralnych zasad wyznaczonych przez godność człowieka i jego nienaruszalne prawa. Podobnie KPP obarczona jest błędem, bowiem wydaje się, że godność winna być nadrzędna nad wolnością, a tak w zapisach Karty nie jest ${ }^{22}$. Dyskusja prawie nigdy nie była wolna od politycznego sporu lewicy z prawicą. Najczęściej kończy się tylko na oskarżeniach i inwektywach o ideologizację. Argument ten można kierować w obie strony. Wiadomo, że jest złudzeniem przekonanie o istnieniu jakiegoś magicznego neutralnego, nowoczesnego, wręcz europejskiego sposobu widzenia ludzkiej płciowości oraz prokreacji. Ten rzekomo nowoczesny sposób realizacji płciowości jest niczym nieograniczony. Powoływanie się na moralne zasady, jest traktowane jako postawy przemocy i represji. Na celowniku winy najczęściej jest system władzy, który generuje formy niesprawiedliwości społecznej. Z drugiej strony, dla prawicy w polskim wydaniu europejskie standardy wolności seksualnej stanowią kryterium relatywizmu moralnego i są traktowane jako symbol cywilizacji śmierci ${ }^{23}$. Bez odszukania obiektywnego punktu odniesienia, bez fundamentu transcendentnego, którego lewica unika, jak gdyby jego przyjęcie było zaparciem się swej tożsamości, niemożliwe jest porozumienie. Jednakże, jak twierdzi najbliższy lewicy John Milbank, przedstawiciel Radykalnej Ortodoksji:

${ }^{20}$ Zob. P. Zychowicz, Eurokraci nie gęsi, "Rzeczpospolita” z 16-17 lutego 2008, s. A22-23.

${ }^{21}$ Tamże, s. A23.

${ }^{22}$ A. Zoll, Polska wobec Karty Praw Podstawowych - streszczenie wystapienia, „Międzynarodowy Przegląd Polityczny" 2008, nr 21, s. 235-236.

23 „Walczymy o antykoncepcję i aborcję nie w imię maltuzjanizmu ani chęci poprawy stanu sanitarnego populacji. Celem naszego ruchu jest akcja na rzecz seksualnego wyzwolenia w walce o wolność socjalną i zmianę społeczeństwa", i dodaje Remi Fontanie, autor Czarnej księgi kultury śmierci, że we Francji ideolodzy rewolucji 1968 oraz współcześni działacze poprzez środki masowego przekazu, akty polityczne i prawne opowiadają się za „niszczeniem życia" embrionalnego, domagają się swobody seksualnej, prawa dla gejów i lesbijek przy adopcji dzieci: F. L. Ćwik, Kultura śmierci, „Nasz Dziennik” z 18 lutego 2008, s. 9. 
Wolność staje się wolnością bez miary i bez celu (without point), wolnością płonną; równość bez podstawy w dobru wspólnym (jako miary podziału według zdolności i wyznaczonej społecznie roli) degeneruje się w traktowanie wszystkich jako formalnie takich samych - co zarówno maskuje, jak i ustanawia faktyczne niewspółmierności. Podobnie braterstwo jest niszczone przez podejrzenie o bardziej fundamentalny egotyzm, jaki wydaje się często schowany pod maską projekcji. [...] Odpowiednio też konkretne lokalne tożsamości, które nie przechowują już transcendencji, są albo odrzucane w imię abstrakcji, czy uniwersalności, albo podtrzymywane z użyciem przemocy kosztem innych tożsamości (bądź też obie te tendencje w przerażający sposób jakoś łączą się ze sobą)"24.

Jak długo jeszcze w europejskiej kulturze będzie rozwijał się dogmatyczny sekularyzm odrzucający transcendentne podstawy poznania i racji działania, tak długo Europa, nawet z prawami zawartymi w KPP, dryfować będzie po bezkresnym oceanie relatywizmu moralnego, a dalej nie będzie w stanie uniknąć rozbicia się o rafy nihilizmu.

W toczącym się sporze, w opinii M. Brachowicza, Karta jest „alienującym [zbiorem] nihilistycznego prawa i wolności"25. Dla zwolenników legalnej aborcji itp. (tak jak wcześniej rezolucja Parlamentu Europejskiego z 4 lipca 2002) niewątpliwie stanowi argument na rzecz swobody i wolności nowoczesnych społeczeństw. Jest to stały argument przeciw fundamentalistycznym przeciwnikom, używających języka cywilizacji śmierci. W takich kategoriach opisuje K. Szczuka polski kształt genderowego konfliktu, omawiając książkę Xavičre Gautier pt. Naissance d'une liberté. Contraception, avortement: le grand combat des femmes au XX-e siécle (Narodziny wolności. Antykoncepcja, aborcja: wielka walka kobiet $w$ wieku $X X)^{26}$.

\section{WARUNKI DYSKURSU SZUKAJĄCEGO SPOŁECZNEGO POROZUMIENIA}

W społeczno-kulturowym dyskursie poszukuje się jakiegoś kryterium. Kiedy jednak prawo narusza godność człowieka, a kiedy nie? W kulturowej przestrzeni Europy nie ma co do tego zgody. Wszystko jest przedmiotem sporu i kontrowersji. Na obecnym etapie społecznego dyskursu takiego porozumienia ani prawdziwego dialogu, ani merytorycznego sporu właściwie nie ma. W sporze strony przyjęły taktykę okopywania się. Zarówno teolodzy, jak i polityczni ideolodzy wypowiadają się z głębi swych światów.

${ }^{24}$ J. Milbank, Program Radykalnej Ortodoksji, przeł. S. Duda, „Krytyka Polityczna” $14(2007 / 2008)$, s. 221.

${ }^{25}$ M. Brachowicz, dz. cyt., s. 31.

${ }^{26}$ K. Szczuka, dz. cyt., s. 258-271. 
Gdyby godność człowieka zapisana w Karcie PP stanowiła fundament prawa, a nie coś, co podlega nieustannej europejskiej interpretacji, sprawa byłaby prostsza. Prawa człowieka jednak nie są wytworem społecznym, ani też nie mogą być wynikiem umowy społecznej, jak chcieliby relatywiści. Jednakże, jak pisze M. Brachowicz: „Po oderwaniu od idei transcendentnej godność staje się ozdobą i hasłem, nie jest wskazówką dla praw, sama staje się przez te prawa determinowana"27. Aby zrozumieć dążenia UE, jej cele oraz sposób działania, trzeba odwołać się do opisu, jaki proponuje Jadwiga Staniszkis. Unia Europejska przeszła już etap uniformizacji w tradycyjnym tego słowa znaczeniu na płaszczyźnie budowania struktur ontologicznych. Pozycję państw członkowskich we wspólnocie jeszcze niedawno określała zdolność „budowania instytucji i efektywność zarządzania publicznego". Ten model jednak już jest nieaktualny. Po Traktacie reformującym funkcjonowanie Unii polega na możliwości tworzenia różnych konfiguracji, ale związków proceduralnych. Granice możliwości stanowią warunki brzegowe. Ważne jest stwierdzenie, że do unijnego prawa "zostały świadomie wprowadzone terminy wieloznaczne”, co pozwala w poszczególnych krajach realizować pod wspólnym szyldem różne cele. Możliwe jest to poprzez

wielość sposobów istnienia prawnych norm raz wiążących a kiedy indziej, jak Karta Praw Podstawowych, tylko prawnie znaczących nawet, gdy się jej nie ratyfikuje: wreszcie dopuszczanie, a nawet - wymaganie - równoczesnego realizowania konfliktowych norm (i manipulowania tylko ich poziomami efektywności - tworzy z Unii twór wielowymiarowy i nie dający się opisać w języku podmiotów i polityki. Coraz mniej jest też użyteczna myślowa kategoria różnicy, a wraz z tym - i dwuwartościowa logika ${ }^{28}$.

W tym opisie zmieniają się reguły gry oraz formy społecznego dyskursu. Zapewne proces ten nie obejmuje jednakowo całej Unii, lecz w różnym stopniu realizowany jest w krajach członkowskich.

Każdy spór lub dialog prawicy z lewicą uwikłany jest skojarzeniami historycznymi, uprzedzeniami wynikłymi z walki o władzę, a nawet ujawnia się ignorancja. Najczęściej strony oskarżają się o egoizm, o brak woli oraz partykularny interes. Chantal Millon-Delsol twierdzi, że punktem wyjścia w dyskusji winna być antropologia. Wartości hierarchizuje się ze względu na koncepcję człowieka. Koncepcja człowieka, odczytanie jego bytu pozwala łatwiej odpowiedzieć na pytanie: „Jak uczynić społeczeństwo lepszym i bardziej

${ }^{27}$ M. Brachowicz, dz. cyt., s. 15.

${ }^{28} \mathrm{http}: /$ wiadomości.wp.pl/wiadomosc.html?kat=88034\&wid=9679494\&rfbawp=12035... (dostęp 21.02.2008). 
sprawiedliwym?"29. Prawica wierzy, „że w człowieku dobro jest splatane ze złem”, a lewica, że zło pojawiło się wraz z własnością prywatną (Rousseau), małżeństwem (Engels), z klasami społecznymi (Marks). „W tym sensie prawica wpisuje człowieka w „naturę” przenikniętą złem, podczas gdy lewica widzi w człowieku istotę nieokreśloną, która może stać się, czym chce, jak twierdził Sartre, podążając dawnym śladem Pico de la Mirandoli" ${ }^{30}$. W sumie błędem jest przekonanie, że wyzwolenie człowieka ze zła możliwe jest poprzez wyzwolenie go ze struktur społecznych i z drugiej strony, że „losem ludzkim rządzi tylko niezmienna «natura»", twierdzi Ch. Millon-Delsol ${ }^{31}$.

Publicysta katolicki ujmuje to ostrzej: „Współcześni głosiciele postępu uznają, że szczęście ogarnie wszystkich, gdy tylko zniszczy się tradycyjne struktury życia społecznego, takie jak rodzina i zastąpi się je tonami zapisanego papieru określającego, co jest, a co nie jest prawem człowieka"32. Gdy więc „nikt albo prawie nikt nie wierzy już w niezmienną «naturę» [człowieka] ani, odwrotnie, w możliwość tabula rasa”, i chociaż „możemy wszystko (na przykład zmienić mężczyznę w kobietę albo wyprodukować klony), nie wszystko możemy zrobić bezkarnie" ${ }^{\prime 33}$. Pytanie więc dotyczy granicy, jak daleko można się posunąć. Ta granica dzieli liberalizm od konserwatyzmu, lewicę od prawicy. Prawica sądzi, że człowieka nie można wyzwolić z jego paradoksów egzystencji, pozbawiając się religii, ekonomii, instytucji czy moralnej oceny tego, co jest dobrem, a co jest złem. Natomiast trzeba zachować "sam rdzeń ludzkiej kondycji”. Dalej wyżej przywołana Ch. Millon-Desol twierdzi, że „autonomia stanowi centralną wartość zachodniej kultury; można by zatem znieść klasyczną rodzinę lub własność prywatną, ale tylko znosząc zarazem wolność i odpowiedzialność jednostek" ${ }^{\prime 34}$. Ale życie tworzy właśnie wysiłek jednostek, wartością jest kultura osoby i podmiotu, przeciwne działania są skierowane przeciwko spójności zachodniej kultury. Inny wymiar sporu dotyczy tego, co szczegółowe, z tym, co uniwersalne. Lewica, wiążąc się z tym, co uniwersalne, jest zachwycona KPP, jako „uniwersalnym systemem wartości”, tym samym ignorując osobliwości kultur narodowych. Według myślicieli prawicowych, bez zakorzenienia w tym, co szczegółowe, nie można dążyć do tego, co uniwersalne. Najpierw trzeba być obywatelem konkretnego kraju, aby być obywatelem UE, najpierw trzeba być dzieckiem lub mężczyzną, lub kobietą, aby nie zagubić ludzkiej godności ${ }^{35}$. Pa-

${ }^{29} \mathrm{Ch}$. Millon-Delsol, O potrzebie nowego ugruntowania prawicy, przel. M. Kowalska, „Krytyka Polityczna” 2 (2002), s. 149-151.

${ }^{30}$ Tamże, s. 152.

${ }^{31}$ Tamże, s. 152.

32 T. P. Terlikowski, dz. cyt., s. 17.

${ }^{33}$ Ch. Millon-Delsol, dz. cyt., s. 153.

${ }^{34}$ Tamże, s. 156.

${ }^{35}$ Tamże, s. 156-157. 
radoks konfliktu wygląda tak, jak gdyby prawica w imię natury broniła tego, co jest złe, wziąwszy pod uwagę wszelką przemoc związaną z zagadnieniem płci i seksualności, natomiast lewica w imię ludzkiego współczucia ignoruje naturę. Jak to możliwe? Umiarkowana prawicowa intelektualistka Ch. Millon-Delsol odpowiada, że "Chorobą prawicy jest raczej rodzaj fatalizmu. Podczas gdy woluntaryzm lewicy może prowadzić do diabelskiej lub demiurgicznej pychy. Pokora prawicy w obliczu konieczności może prowadzić do uległej akceptacji losu, do filozoficznego esencjalizmu, który uświęca mniej lub bardziej, fikcyjną ludzką »naturę«"36. Konstruktywistyczny socjalizm, walcząc o wyzwolenie człowieka z nędzy i ucisku, pokazał, jak wiele w drodze do wolności, równości i dobrobytu trzeba płacić, ignorując, jeśli nie naturę, to ludzką kondycję ${ }^{37}$. Zazwyczaj konflikt wywołują skrajne rozwiązania. Jeśli jedna strona uważa człowieka za czysty projekt, który można dowolnie tworzyć, to druga strona, odwołując się do natury, zbyt radykalnie zamyka pole wolności. Podczas gdy Chantal Delsol zwraca uwagę na naturę, ale i na to, że człowiek jest jeszcze $\mathrm{w}$ stanie tworzenia samego siebie. Otwarty $\mathrm{z}$ natury jest bowiem na historię. Biologia nie wyznacza całego sensu bycia człowiekiem, i na samej biologii nie można wyznaczyć sensu bycia osobą ${ }^{38}$.

Samo wskazanie na skutki i okrucieństwa z powodu idei „wyzwalania” $\mathrm{w}$ imię sprawiedliwości społecznej jest w złym guście, a „Asymetria moralna - przywłaszczenie sobie przez lewicę całej historii ludzkich cnót - idzie $\mathrm{w}$ parze $\mathrm{z}$ asymetrią logiczną, a mianowicie z założeniem, że ciężar dowodu spoczywa zawsze na przeciwniku" ${ }^{\prime 39}$. Paradoksem jest też to, że nie sposób uniknąć dyskusji na temat rewolucji genderowej w kategoriach sporu lewicy z prawicą. Już ten paradoks zmusza do uznania, że w ludzkim świecie moralności i polityki społecznej nie wszystko jest dowolne, a gdy przekroczy się pewne granice, skutki bywają szokujące. Nie sposób szukać punktów stycznych, zaczynając od pytań podstawowych o prawdę, o człowieka, o możliwość wolności, jeśli założy się działanie materialistycznych i deterministycznych sił, uwzględniając ewentualnie konsumpcjonizm. Jeśli jednak podejmuje się dyskusję, winna ona być maksymalnie odpolityczniona, na tyle, na ile jest to możliwe, inaczej dwa światy pozostaną obok siebie obce i walczące. Przy-

${ }^{36}$ Tamże, s. 158.

37 „Albowiem ludzka kondycja nie wyłania się w czystej postaci z życiowego doświadczenia. Wprawdzie w przeciwieństwie do tego, co może sądzić lewica, żaden system nie może zakorzenić się bezpośrednio w moralności nie rodząc terroru, ale też żaden system nie zakorzenia się bezpośrednio w naturze, chyba że kosztem cynizmu lub fatalizmu, które zresztą chodzą ze sobą w parze" - tamże, s. 158-159.

${ }^{38}$ Ch. Delsol, Esej o człowieku późnej nowoczesności, przeł. M. Kowalska, Kraków 2003, s. 147

${ }^{39}$ R. Scruton, dz. cyt., s. 18-20. 
kładowo, zakazuje się dyskryminacji ze względu na płeć, ale też nie widać porozumienia $\mathrm{w}$ kwestii uznania pracy kobiet $\mathrm{w}$ domu. Opieka nad dziećmi jako praca pielęgnacyjna, ochronna i wychowawcza dzieci nie znajduje uznania $\mathrm{w}$ ocenach europejskich polityków. Takie traktowanie kobiet nie jest uznawane za dyskryminację, pomimo problemów demograficznych oraz z tym związanych niebezpieczeństw ekonomicznych oraz gospodarczych. Dzieje się tak, ponieważ „Przez ponad trzy dekady radykalne feministki atakowały i poniżały instytucję małżeństwa. Przedstawiały małżeństwo jako układ ekonomicznie wykorzystujący kobiety oraz jako więzienie powodujące rozpacz i choroby umysłowe u kobiet pozostających w związku małżeńskim"40. Stary radykalny feminizm przez propagowanie totalnej wojny kobiet z mężczyznami był z natury antyrodzinny, był skrajną reakcją na zadania matki lub rolę żony. Umiarkowane ruch feministyczne używają bardziej stonowanych ocen i mniej radykalnego języka konfrontacji.

Czy można w dziedzinie polityki demograficznej lekceważyć opinię typu: „Model szwedzki, polegający na państwowych zasiłkach na dzieci, prawie obowiązkowe zatrudnienie matek, ubezpieczenie rodzicielskie, opieka przedszkolna i równowaga płci we wszystkich dziedzinach życia człowieka, nie sprawdził się. Obecna obsesja europejskich naukowców i polityków na punkcie tego modelu jako odpowiedzi na problemy demograficzne Europy jest złudzeniem i ślepym zaułkiem". Dr Allan C. Carlton formułujący takie oceny, podpowiada model amerykański, oparty na nauce $\mathrm{w}$ domu, obniżeniu podatków w zależności od liczby dzieci, także poprzez wzmocnienie wartości wiary religijnej i szacunku do naturalnych uzupełniających się ról mężczyzny i kobiety ${ }^{41}$. Dlatego formułuje się opinię, że „Parlament Europejski akceptuje rozwiązania sprzeczne z interesem nie tylko poszczególnych krajów członkowskich, lecz także Unii jako wspólnoty", bowiem jeśli prawo nie definiuje istoty małżeństwa, będąc otwarte na różne rozwiązania, istnieje obawa, iż imigrant z innej kultury praktykujący wielożeństwo ma równe prawa np. do zwielokrotnionych socjalnych zasiłków, jak to jest w przypadku małżeństwa monogamicznego. Czy unijne instytucje skłonne są zaakceptować każdy model małżeństwa? ${ }^{42}$ Porozumienie jest niemożliwe na gruncie marzeń fundamentalistów o istnieniu jednolitego moralnie i religijnie społeczeństwa, a także na gruncie dawnych sekularystycznych ideologii ${ }^{43}$.

${ }^{40}$ P. F. Fagan, R. E. Retor, L. R. Noyes, Dlaczego Kongres USA powinien zignorować feministki, "Międzynarodowy Przegląd Polityczny" 10 (2004/2005), s. 47.

${ }^{41}$ A. C. Carlson, dz. cit., s. 119; A. C. Carlson, P. T. Mero, O naturalny charakter rodziny, „Międzynarodowy Przegląd Polityczny” 14 (2006), s. 103-121.

${ }^{42}$ A. Wiejak, Recepta na pogłębienie kryzysu, "Nasz Dziennik” z 22 lutego 2008, s. 7.

${ }^{43}$ M. Warchała, Co to jest postsekularyzm (subiektywna próba opisu), „Krytyka Polityczna” 13 (2007), s. 187. Autor artykułu kończy znamiennym stwierdzeniem: „Wywody Kepela, tak jak i obserwacje Bergera, filozoficzne rozmyślania Voegelina czy niepokoje Webera pokazują 
Złotego środka jakiegoś porozumienia poszukuje Rocco Buttiglione. W istocie chodzi mu o wartości, z których przedstawiciele prawicy nigdy zrezygnować nie mogą, a także, by na gruncie nie tylko emocjonalnym, ale i rozsądku szukać porozumienia. Widzi, jak trudno rozmawiać w nurcie metafizycznym, dlatego proponuje podejście fenomenologiczne. $W$ ten sposób pragnie pogodzić interes wspólnoty z interesem obywatela ${ }^{44}$.

Ukłon wobec autorytetów winien uwzględnić glos Jürgena Habermasa, który po wielu latach intelektualnych oraz politycznych doświadczeń wreszcie stwierdza: „Jedna strona obawia się obskurantyzmu i konsolidacji tego, co pozostało z archaicznych emocji antynaukowych, druga strona zwracała się przeciwko bezwzględnemu naturalizmowi i scjentystycznej wierze w postęp, widząc w nich zagrożenie dla moralności" ${ }^{45}$. Trudno $\mathrm{w}$ tym miejscu podejmować dyskusję na temat tego, czy rzeczywiście prawa strona jest antynaukowa, czy tylko antydogmatyczna, i nie tylko ma intuicje zagrożeń, lecz bazuje na kulturowym doświadczeniu wieków. Jednakże wybierając z wypowiedzi to, co ważne jest w tym sporze, jaki toczy się obecnie w Unii, widać niewspółmierność sił, ponieważ według J. Habermasa powinno być tak, że „w sporze między roszczeniami wiedzy i wiary państwo światopoglądowo neutralne bynajmniej nie faworyzuje jednej strony"46. Dlaczego? Bowiem "Scjentystyczna wiara w naukę, która pewnego dnia nie tylko uzupełni, ale zastąpi osobową samowiedzę przez obiektywizujący opis, nie jest nauką, lecz kiepską filozofią" ${ }^{\prime 7}$. Niemniej, łamiąc konsekwencje myślowe, ten krytyczny filozof społeczny sympatyzujący z myślą Marksa oraz wierzący w jedność poznania i działania domaga się od ludzi wierzących uznania autorytetu nauk, które mają monopol na wiedzę, uwzględnienia propozycji innych religii oraz uznania moralności świeckiej państwa konstytucyjnego ${ }^{48}$. Habermas kończy swoją wypowiedź ostrzeżeniem, a może bardziej pytaniem, które dotyczy obu stron sporu: „Czy pierwszy człowiek, który według własnego upodobania określi, jaki ma być z natury inny człowiek, nie zniszczy siłą rzeczy owych jednakowych wolności, które przysługują ludziom równym z urodzenia, aby zagwarantować ich różność?"49.

też jeszcze jedno: po klęsce teorii sekularyzacji wciąż brakuje nam prawdziwie postsekularnego myślenia o religii - myślenia, które ostatecznie złoży sekularyzacyjną ortodoksję do grobu i będzie w stanie uchwycić wszystkie społeczne i polityczne zjawiska w których religia ma swój istotny udział" - tamże, s. 188.

${ }^{44}$ R. Buttiglione, Nowa koncepcja praw człowieka, przeł. A. Legutko-Dybowska, „Więź” 2008, nr 2-3 (592-593), s. 62-71.

${ }^{45}$ J. Habermas, Wierzyć $i$ widzieć, przeł. M. Łukasiewicz, „Znak” 2002, nr 9, s. 8.

${ }^{46}$ Tamże, s. 12.

${ }^{47}$ Tamże, s. 14.

${ }^{48}$ Tamże, s. 11.

${ }^{49}$ Tamże, s. 21. 
Można wskazać pewne przejawy społecznego dialogu i poszukiwań wewnątrz chrześcijaństwa i Kościoła w Polsce na tle postmodernistycznego kotła. Najczęściej są to liberalne postulaty odrzucenia tradycji, doktryny, zgody na sekularną erozję. Najlepiej jednak, by Kościół w procesie laicyzacji, budowania nowoczesności oraz modernizacji nie wtrącał się i usunął się do krużganka prywatności, gdzie jest jego miejsce ${ }^{50}$. Takie głosy też się zdarzają. Zapomina się, że propozycje właściwe procesom sekularyzacji Europy oraz postmodernistycznej kultury również są częścią systemu społecznej represji. Na dobrą sprawę w społecznym sporze równie dobrze spotykać się może fundamentalistyczna teologia z fundamentalistycznym naukowym pozytywizmem ${ }^{51}$.

Patrząc na dzieje sekularyzacji w Europie od czasu rewolucji francuskiej, Benedykt XVI przestrzega przed fałszywą wizją postępu, który zgodnie z przekonaniem I. Kanta prowadzi do „perwersyjnego końca”, a według Th. W. Adorna, którego papież przywołuje mówiąc o nadziei, postęp naukowy prowadzi „od procy do megabomby”. Papież jest przekonany o konieczności dialogu, ale najpierw:

Konieczna jest samokrytyka czasów nowożytnych w dialogu z chrześcijaństwem i jego koncepcją nadziei. W tym dialogu również chrześcijanie, w kontekście ich wiedzy i doświadczeń, winni na nowo uczyć się, czym jest ich nadzieja, co mają do zaoferowania światu, a czego natomiast nie mogą ofiarować. Trzeba, aby z samokrytyką czasów nowożytnych łączyła się samokrytyka nowożytnego chrześcijaństwa, które wciąż od nowa musi uczyć się rozumienia siebie samego, poczynając od swych korzeni (Spe Salvi 16-22).

Oczywiście myliłby się ten, kto rozumiałby samokrytykę jako rezygnację z prawdy lub rozmycie kryteriów podstawowej wykładni prawd moralnych.

50 T. P. Terlikowski, Kościót, modernizatorzy, monolog, „Rzeczpospolita” z 23-24 lutego 2008, s. A16-A17. „Kościół odrzucający własne roszczenia do nieomylności, rezygnujący z nauczania, a zamiast tego wędrujący wraz z ludźmi po drogach ich życiowych wyborów, ale niczego nienarzucajacy - taki obraz wymarzonej wspólnoty religijnej wyłania się z lektury „Gazety Wyborczej” i „Dziennika”.

${ }^{51}$ S. Duda, Między Chrystusem a Antychrystem, czyli radykalny ortodoks chrześcijański spotyka lewice, „Krytyka Polityczna” 14 (2007/2008), s. 204-206, 208-211. Czołowy przedstawiciel teologii Radykalnej Ortodoksji John Milbank „w swym podstawowym dziele Theology and Socjal Theory stwierdza, że nowożytne próby wyznaczenia społecznej rzeczywistości poza naszym uczestnictwem w boskim objawieniu Logosu w Chrystusie oparte są na podstawowym akcie przemocy [...] Aby bez Boga zbudować nasze ziemskie państwo i aby określić tożsamość człowieczeństwa, na którym ma się oprzeć polityczna i moralna refleksja, musimy zdeformować i zniszczyć nasze właściwe człowieczeństwo stworzone po to, abyśmy mieli udział w mieście niebiańskim (nowym Jeruzalem z Apokalipsy wg św. Jana) nie tylko w spełnionym eschatonie, ale również w naszym ziemskim tu i teraz" - tamże, s. 206. 


\section{ZAKOŃCZENIE}

Świat, Europa i Unia Europejska nieustannie się zmieniają. W przestrzeni polityczno-kulturowej o wpływy w kształtowaniu prawa i życia udział biorą różne podmioty, które $\mathrm{w}$ pewnym uproszczeniu można podzielić na prawicę i lewicę. Liberalny laicyzm w kwestii rozumienia znaczenia i praktyki wobec równości płci (gender mainstreaming) zdobył miejsce w prawnej ochronie, jaką jest KPP UE. Jest to dążenie do nieskrępowanej wolności moralnej, właściwie bez uwzględniania dalszych konsekwencji. $Z$ jednej strony jest to europejskie osiągnięcie, ale budzi wiele zastrzeżeń, zwłaszcza co do braku definicji pojęć, ich wieloznaczności oraz niemożliwych do wypełnienia zapisów. Istnieje obawa co do kierunku oraz dynamiki interpretacji praw podstawowych przez Trybunał Praw Człowieka. Prawodawstwo krajowe w pewien sposób ogranicza ten zakres, jednakże kraje, które ratyfikują KPP, tak jak instytucje europejskie, będą prawnie nią związane.

Liberalna pragmatyka formułuje oceny, że z religijnego punktu widzenia teolodzy-moraliści szukają diabła tam, gdzie go nie ma. Zresztą jakiekolwiek zastrzeżenia na temat godności, której nie interpretuje się w paradygmacie europejskim, pomijając naturalne lub religijne odniesienie laicyzm liberalny, odbiera jako działania niebezpieczne i groźne przeciw wolności człowieka. Przeciwny tym liberalnym tendencjom głos w dyskusji psuje komfort dobrego samopoczucia lewicy. Organizowane kampanie przeciw homofobii w istocie dążą do prawnego zakazu wolnej wypowiedzi zawierającej moralne kwalifikacje. Już sama krytyczna ocena może być uznana za przejaw dyskryminacji. KPP UE nie promuje takich działań, ale je umożliwia. Dodatkowo nie jest to już tylko spór kulturowy, lecz realny w wymiarze społecznej praktyki. W przekonaniu wielu intelektualistów, którym zależy na harmonii wolności indywidualnych i obywatelskich, konieczny jest zatem społeczny dyskurs. Skrajny liberalizm, dogmatyczny scjentyzm, jak i uprzedzenia nie pozwalają na wypracowanie społecznego porozumienia. Niniejszy artykuł jest próbą udziału w określeniu stanowisk liberalnej lewicy i przedstawicieli tradycji chrześcijańskiej, jak też dążeń społecznych oraz możliwości wspólnego budowania przyszłości Europy.

\section{ANTAGONISM AND DIALOGUE OPPORTUNITY IN THE EUROPEAN ARGUMENT ABOUT GENDER}

\section{SUMMARY}

The author discusses the problems of the ongoing argument about gender in the European culture. The argument results from the processes of cultural changes, which have started in Europe at the beginning of 20th century. In the half of the century the argument took on a form of a confrontation with a traditional ethics which resulted 
in a culture revolution 68 . The basis of these processes is the philosophy of rejecting the concept of natural law for the sake of a social agreement. A specific support of an argument concerning the new understanding of the meaning and the role of a gender and any practice connected with this issue came from the new anthropology of K. Marx, Martina Heidegger, Sigmund Freud, Jean Paul Sartre, Simone de Beauvoir. The liberal culture and gender politics came into existence under the influence of philosophic views. It negates the historic, philosophic and theological sources of the European civilisation. It creates the new axiology, the new law, which results in the EU Basic Laws Card, by some environments was accepted as a manifesto of liberal trends, the support of a fighting feminism, leftist and gay organizations. The opposed side is the European right, frequently connected with a christian culture. Between these sides arises the argument and even a political fight. In order to move from the permanent social antagonism to any status quo, to any modus vivendi, common compromise, there is a necessity of creating a new dialogue. The author describes a proposal and the area of a dialogue in the version offered by Chantal Millon-Delsol, who tries to detect this what divides the left with the right and where is the opportunity of meeting in an intellectual dialogue. The author of the article quotes the opinion of Benedykt XVI, who calls on the right to listen to the voice of the left, but also calls on the left to include social consequences of the forced moral liberalism. The situation of the argument would be different if the left had included the representatives of Frankfurt school: Jürgen Habermas, Max Horkheimer, Theodor Wiesengrund Adorn, or Ernst Bloch, who detected a positive role of religion in searching for the European ethical standards. 